\title{
Ecosystem services of runoff marshes in urban lowland basins: proposals for their management and conservation
}

\author{
Laura C. Armendáriz ${ }^{1,2, *}$, Bianca Cortese ${ }^{1,2}$, Marianela Rodriguez ${ }^{1,3}$ and Alberto Rodrigues Capítulo ${ }^{1,2}$ \\ ${ }^{1}$ Instituto de Limnología "Dr. Raúl A. Ringuelet” (ILPLA, CONICET La Plata-UNLP), La Plata, Argentina \\ ${ }^{2}$ Facultad de Ciencias Naturales y Museo, UNLP, La Plata, Argentina \\ ${ }^{3}$ Facultad de Ciencias de la Salud, UNER, Concepción del Uruguay, Argentina
}

\begin{abstract}
The city of La Plata, Argentina, is situated in a low alluvial zone, with streams having insufficient drainage into the Río de la Plata estuary. In April 2013, a prodigious storm front caused unprecedented flooding in the city and environs that resulted in extensive loss of life and property, especially in the Del Gato stream basin. Through an analysis of water quality and the conditions of the habitat on the basis of the macroinvertebrates present as bioindicators of environmental quality, this work aims to contribute to a reevaluation of the role of the marshes adjacent to the stream as flood-alleviation elements, and then propose alternatives for flooding management in the basin. Consequently, quantitative seasonal samples of vegetation, sediments, and benthic organic matter were taken and limnologic parameters measured in three sectors of the basin having different land uses: rural, periurban, and urban-industrial. The macroinvertebrate assemblages, as analyzed through the application of ecological indices, exhibited a marked decline in richness and in the Pampean Biotic Index towards the low-lying basin. Principalcomponents analysis associated Site 1 with the dissolved-oxygen concentration, Site 2 with high nitrate values, and Site 3 with oxygen demands. Redundancy analysis indicated a positive relationship between Baetidae and Aeolosomatidae with the dissolved-oxygen concentration and between Enchytraeidae and Stratiomyidae with the conductivity. These marshes are fundamental in maintaining good environmental conditions and attenuating the effects of the flooding that is predicted to become increasingly catastrophic in this region as the climate changes.
\end{abstract}

Keywords: aquatic invertebrates / environmental integrity / biotic index / taxon richness / Argentina

Résumé - Les services écosystémiques des marais collatéraux dans les bassins urbains de plaine: propositions pour leur gestion et leur conservation. La ville de La Plata, en Argentine, est située dans une zone alluvionnaire, avec des cours d'eau ayant un écoulement insuffisant dans l'estuaire du Río de la Plata. En avril 2013, un front de tempête exceptionnel a causé des inondations sans précédent dans la ville et dans les environs, qui a entraîné des pertes en vie humaine et en propriétés, en particulier dans le bassin de Del Gato. Grâce à une analyse de la qualité de l'eau et des conditions de l'habitat sur la base des macroinvertébrés présents en tant que bioindicateurs de la qualité de l'environnement, ce travail vise à contribuer à une réévaluation du rôle des marais adjacents à la rivière en tant qu'éléments d'atténuation des inondations et propose ensuite des solutions alternatives pour la gestion des inondations dans le bassin. Simultanément des échantillons saisonniers quantitatifs de végétation, de sédiments et de matières organiques benthiques ont été pris et des paramètres limnologiques mesurés dans trois secteurs du bassin ayant des utilisations de terres différentes : rurales, périurbaines et urbaines-industrielles. Les différences de macroinvertébrés, analysées par l'application d'indices écologiques, ont montré un déclin marqué de la richesse et de l'indice biotique Pampean vers l'aval. L'analyse en composantes principales associe le site 1 avec la concentration en oxygène dissous, le site 2 avec des valeurs élevées de nitrate et le site 3 avec des demandes en oxygène. L'analyse de redondance a indiqué une relation positive des Baetidae et Aeolosomatidae avec la concentration en oxygène dissous et des Enchytraeidae et Stratiomyidae avec la conductivité. Ces marais sont fondamentaux pour maintenir de bonnes conditions environnementales et

\footnotetext{
${ }^{*}$ Corresponding author: larmendariz@ilpla.edu.ar
} 
atténuer les effets des inondations qui devraient devenir de plus en plus catastrophiques dans cette région à mesure que le climat change.

Mots-clés : invertébrés aquatiques / intégrité environnementale / index biotique / richesse taxonomique / Argentine

\section{Introduction}

La Plata, founded in 1882 , is one of the few cities - along with Washington D.C., Canberra, and Brasilia - that was planned and constructed specifically to serve as a state capital. The city is the product of the largest architectural and urbanistic proposal that has been undertaken in Argentina. La Plata was founded to be an advanced city, conceived and designed at the end of the nineteenth century to accommodate more than 100000 inhabitants. The city's plan and construction was received with great admiration in the 1889 International Exhibition in Paris, causing a widespread enthusiastically positive impression internationally (Morosi, 1999). The city was projected in the classical rectangular grid pattern characterized by the concept of symmetrical geometry and in accordance with the hygienic attitudes of the urbanists of the nineteenth century, whose interests in public health were aimed at overcoming the problems caused by an industrial city. The perfect square of the city's design is delimited by a surrounding boulevard, whose layout is superimposed over the central orthogonal grid along with a network of diagonal avenues therein that form diamondshaped sectors alternately demarcating residential neighborhoods, provincial administrative seats, and numerous green areas in the form of plazas and parks (Díaz, 1982). Nevertheless, in spite of the founders' original intentions, the city has undergone an astounding and uncontrolled urban development in recent decades to now become the fourth most highly populated city in Argentina with 750000 inhabitants (Censo argentino 2010).

La Plata is situated in a low lying alluvial zone of flat topography and deficient drainage effected through watercourses that empty into the Río de la Plata estuary - e.g., the streams Carnaval, Martín, Rodríguez, and El Pescado; with those all being water bodies of short length that lose great part of their flow through evapotranspiration during periods of low water. The city is divided by two hydric basins - those of the Maldonado and Del Gato streams, the latter one having two tributary streams, the Pérez and the Regimiento, which were buried beneath the historical city center. In particular, the Del Gato stream, like others within the Pampean Ecoregion, is associated with an adjacent marsh that constitutes a low lying zone whose source of affluent water is the runoff from nearby lotic environments. These boggy areas are characterized by a seasonal frequency of excess water without any standard vertical pattern of soil development and thus comprise layers of muddy sediment that result in a prodigious availability of nutrients. The biologic component of greatest duration is the vascular aquatic vegetation that exhibits adaptation to alternative periods of flooding and low water, among other survival strategies. An integral characteristic of these adjacent bogs is their capability of serving as buffer zones attenuating surface runoff, since the vegetation of the plain retains and transforms the excess water coming from the upper stretches of the basin to rechannel those excesses into the river watercourse at the beginning of the next overflow (Neiff, 2001).

In April of 2013, a violent and prolonged storm system produced unprecedented and extensive flooding in the city and periurban areas, causing a number of lives to be lost and major material damage. Within the course of $4 \mathrm{~h}$, more than $300 \mathrm{~mm}$ of water fell, reaching an average intensity of over $100 \mathrm{~mm} \mathrm{~h}^{-1}$ (Romanazzi, 2014). Because of this circumstance, entities of the Argentine state - the National University at La Plata (Universidad Nacional de La Plata) and the National Council of Scientific and Technical Research (Consejo Nacional de Investigaciones Científicas y Técnicas) - conjointly created a collaborative undertaking referred to as the Oriented Research Projects (Proyectos de Investigación Orientados) in order to analyze the environmental and social aspects of regional emergencies. Among those investigations, the multidisciplinary project Evaluation and Analysis of Environmental Risk in the Area of Greater La Plata ("Evaluación y Análisis de Riesgo Ambiental en el Área Gran La Plata") sought to accomplish a comprehensive understanding of the problematic aspects of the Del Gato stream - it forming the principal basin that crosses the city and being, for its part, especially involved in the flooding of 2013.

The monitoring of rivers has been traditionally based on measurements of water quality and the structure of the biota therein, especially through studying the assemblages of fish and invertebrates (Collier, 2008) along with the biofilm (Gómez, 1998). The macroinvertebrates, in particular, constitute a tool that has been widely used for evaluating the ecologic integrity within fluvial systems since that fauna plays a fundamental role in the transfer of energy from the basal sources to the higher consumers. The macroinvertebrates also inhabit different types of smooth or rocky sediments and the macrophytes (Elosegi and Sabater, 2009; Feio and Dolédec, 2012), and likewise are bioindicators of biotic integrity, of the relationship between the use of the land and the territorial ordering (Alberti et al., 2007). They furthermore respond as monitors of the gradient of perturbation on a basin-wide scale (Bunn et al., 2010).

The present work was carried out within the framework of the aforementioned project and includes the studies aimed at assessing the status of the ecologic integrity of the basin. A principal objective was to analyze the quality of the water and the conditions and ecological quality of the habitat through the use of the macroinvertebrates present as bioindicators of environmental integrity. On the basis of this information, the work had as a secondary objective to contribute to a reevaluation of the role of the stream's adjacent bogs within the context of the ecosystem services that they provide to the society at large and to analyze alternatives for the productive management of those marshy areas that are compatible with their sustainable use within the framework of the general plan for the development of healthy urban ecosystems. 


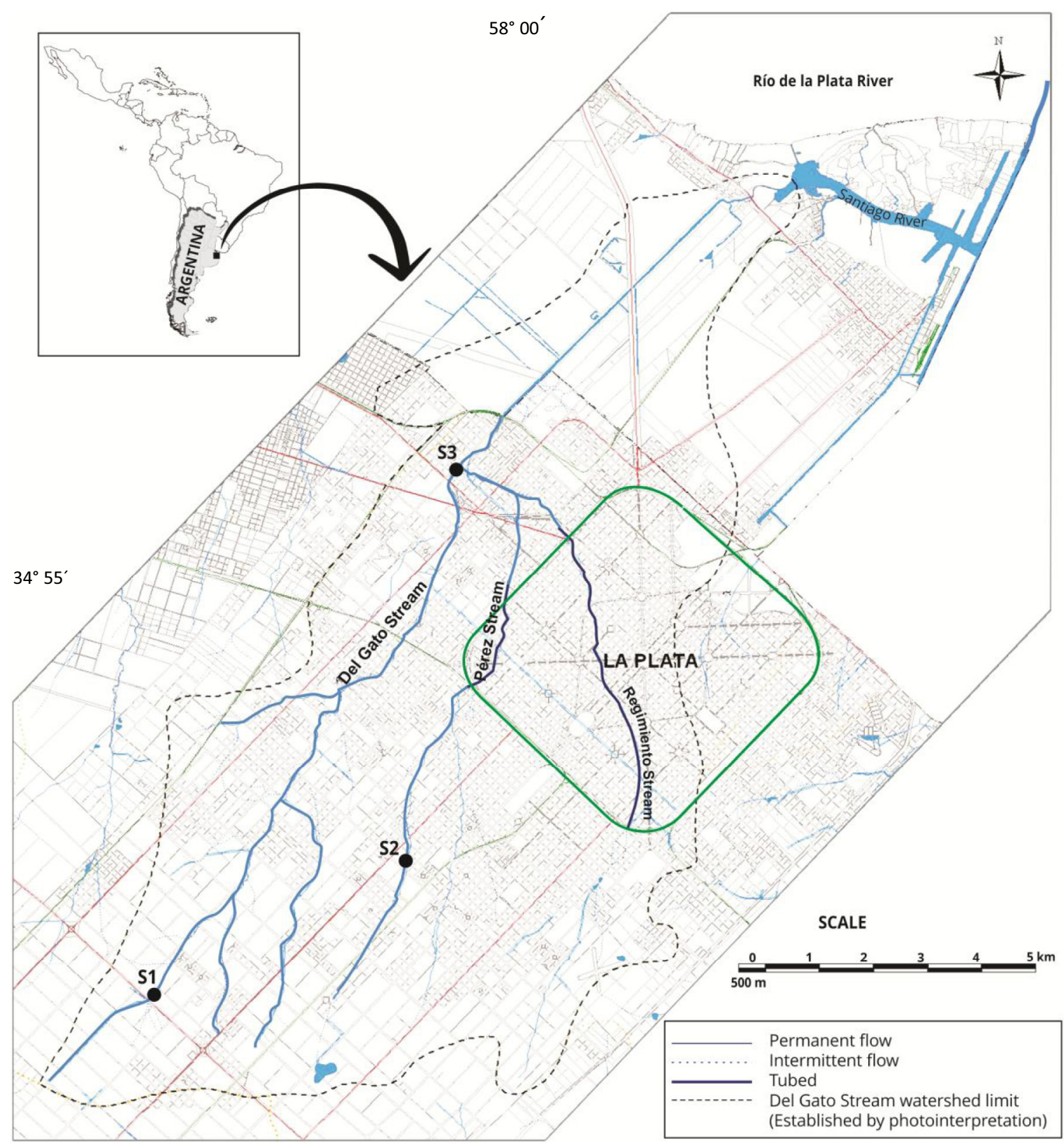

Fig. 1. Map of the city of La Plata and the basin of the Del Gato stream indicating the sampling sites (S1-S3) used in the campaigns of October 2014 through August 2015. The figure is taken from Map N 3 of Cartografía temática ambiental de la Cuenca del Arroyo Del Gato, Partido de La Plata, Provincia de Buenos Aires. Courtesy of Facultad de Ingeniería, Facultad de Ciencias Naturales y Museo, UNLP.

\section{Materials and methods}

\subsection{Study area}

The Del Gato stream - a tributary of the Río de la Plata estuary lying within the Santiago River basin (Fig. 1) - has a length of $25 \mathrm{~km}$ divided into three different sectors: the upper basin, containing an adjacent marsh, that passes through a rural area with intensive use of the soil in fruit and vegetable farming; the middle basin that traverses a periurban zone with additional commercial and industrial activities; and the lower basin, the one containing the highest population density, where precarious dwellings are found in certain sectors located within the stream's floodplain and where inputs from rain overflow, sewer outlets, and industrial effluents enter directly into the stream's discharge. In addition, towards the mouth of the stream, the watercourse undergoes major modifications in its trajectory resulting from rectifications and canalizations. With respect to these types of man-made alterations, two tributaries of the Del Gato stream - the Pérez and the Regimiento streams - having been buried, flow underneath the historical portion of the city. In this section of the lower basin, hydraulic works are being undertaken at the present time. More than 400000 people have been estimated as inhabiting the basin, which is about $50 \%$ urbanized (Gómez et al., 2016). 
The climate in the region is temperate with an average temperature of $16.3^{\circ} \mathrm{C}$, with summer maximum and winter minimum temperatures of 39 and $-5.7^{\circ} \mathrm{C}$, respectively. The proximity of the region to the Río de la Plata estuary produces an elevated relative humidity at an average annual value of $80 \%$. The mean precipitation level during the year is some $990 \mathrm{~mm}$, with summer being the principal rainy season followed by spring and autumn. Snowfalls are atypical and most infrequent, such that only five have occurred since the founding of La Plata.

\subsection{Collection of macroinvertebrates}

During 2014 and 2015, quantitative seasonal samples of vegetation and sediments were taken in the three sectors of the basin: Site 1 in an adjacent marsh of the Del Gato stream surrounded by land of rural use, Site 2 in the Pérez stream within a stretch passing through a periurban zone, and Site 3 in the Del Gato stream in an area of urban and industrial use and with precarious dwellings (Fig. 2). The samples of vegetation were taken with a $30-$ by $-30-\mathrm{cm}$ plexiglass square and the macrophytes there transferred to bags with a sieve of mesh size $250 \mu \mathrm{m}$. The sediment samples were extracted with a 10-by10-cm Ekman dredge. All the sampling was performed in triplicate and the specimens obtained fixed in 5\% (v/v) aqueous formalin.

\subsection{Sampling of the water for physicochemical analysis}

The following physicochemical parameters were also measured: temperature, $\mathrm{pH}$, turbidity, conductivity, and dissolved-oxygen concentration. Water samples were also taken for a later determination in the laboratory of $\mathrm{P}_{-} \mathrm{PO}_{4}{ }^{-3}$, $\mathrm{N}-\mathrm{NO}_{3}{ }^{-}, \mathrm{N}-\mathrm{NO}_{2}{ }^{-}, \mathrm{N}-\mathrm{NH}_{4}{ }^{+}$, and the biochemical and chemical oxygen demands.

\subsection{Sample processing and taxonomic characterization}

In the laboratory, the samples were washed with running water on a $500 \mu \mathrm{m}$ mesh sieve and then stained with erythrosin $\mathrm{B}$ for a more facile identification and separation of the organisms. The macroinvertebrates collected were characterized by optical (Olympus CX31) and binocular stereo(Olympus SZ61) microscopy through the use of the keys from Brinkhurst and Marchese (1992), Domínguez and Fernández (2009), Lopretto and Tell (1995a, b), and Merritt et al. (2008). After identification, the organisms were preserved in $70 \%(\mathrm{v} / \mathrm{v})$ aqueous ethanol. The vegetation was characterized down to the species level according to the taxonomic criteria of Cabrera and Fabris (1948).

\subsection{Quantitation of organic matter}

The content of organic matter in the sediment was determined by the method of weight loss upon ignition (i.e., loss of organic matter on ignition, LOI): here, the sample was first dried to constant weight at $60^{\circ} \mathrm{C}$ and then charred at
$500{ }^{\circ} \mathrm{C}$ for $4 \mathrm{~h}$ in a muffle furnace. An analytical balance of precision down to $0.01 \mathrm{mg}$ (Ohaus Explorer E00640 Class I) was used to measure the ash-free dry weight of the samples.

\subsection{Characterization of the macroinvertebrate assemblage}

The macroinvertebrate assemblage was analyzed by means of the following biotic and ecological indices: taxon richness, the Shannon diversity index $\left(\mathrm{H}^{\prime}\right.$; Shannon, 1948) plus the biascorrected $\mathrm{H}^{\prime}$ (the exponent of the $\mathrm{H}^{\prime}$ value), and the biotic index for the pampean rivers (i.e., indice biótico para los invertebrados pampeanos, IBPamp). The bias-corrected $\mathrm{H}^{\prime}$ is considered to be the most appropriate estimate of diversity since that index weighs each species according to its relative abundance, and the parameter approaches a value of unity (1) as a limit. This limiting value, accordingly, is equivalent to the exponential of $\mathrm{H}^{\prime}$ (Jost and González-Oreja, 2012). The IBPamp, however, is a regional construct on the basis of the local features of the rivers and streams within the pampean area that takes into account the different degrees of sensitivity of the autochthonous aquatic macroinvertebrates and the number of taxa present at each site evaluated (Rodrigues Capítulo, 1999; Rodrigues Capítulo et al., 2001). The indices of benthic biologic integrity are considered to be robust determinations for characterizing the ecologic condition of the rivers and as such are appropriate for diagnosing the causes of ecologic disturbance in addition to suggesting the necessary steps for achieving an adequate management of those environments (Karr, 1991). Within this context, the IBPamp has been employed as a descriptor for the monitoring that has been performed since 2008 within the Comprehensive Plan for Promoting Environmental Well-being (Plan Integral de Saneamiento Ambiental) in the Matanza Riachuelo hydrographic basin, the most highly populated and contaminated one in all of Argentina (Rodrigues Capítulo et al., 2016). Both for the richness and diversity indices and for the IBPamp, the taxonomic category used was the family.

The total density of individuals was estimated and the percentages of taxa that were sensitive, tolerant, and highly tolerant to contamination were assessed.

\subsection{Statistical analyses}

The analysis of variance (ANOVA) with repeated measurements was performed in order to analyze the differences between the sites and between the measurement dates at a given site with respect to the ecologic and biotic indices, the density of individuals, and the proportion of sensitive taxa. The method of Shapiro-Wilk was used to test the normality and the a-posteriority method of multiple comparison of Holm-Sidak employed at a significance level of $p \leq 0.05$ to isolate the group or groups that differed from the rest (Sigma Plot 12.0). Finally, the relationship between the abundance of macroinvertebrates and the content of organic matter was analyzed by means of Pearson's correlation coefficient.

The affinity between the sampling sites and the standardised physicochemical variables was investigated by principal-components analysis (PCA), while a detrended 
(a)

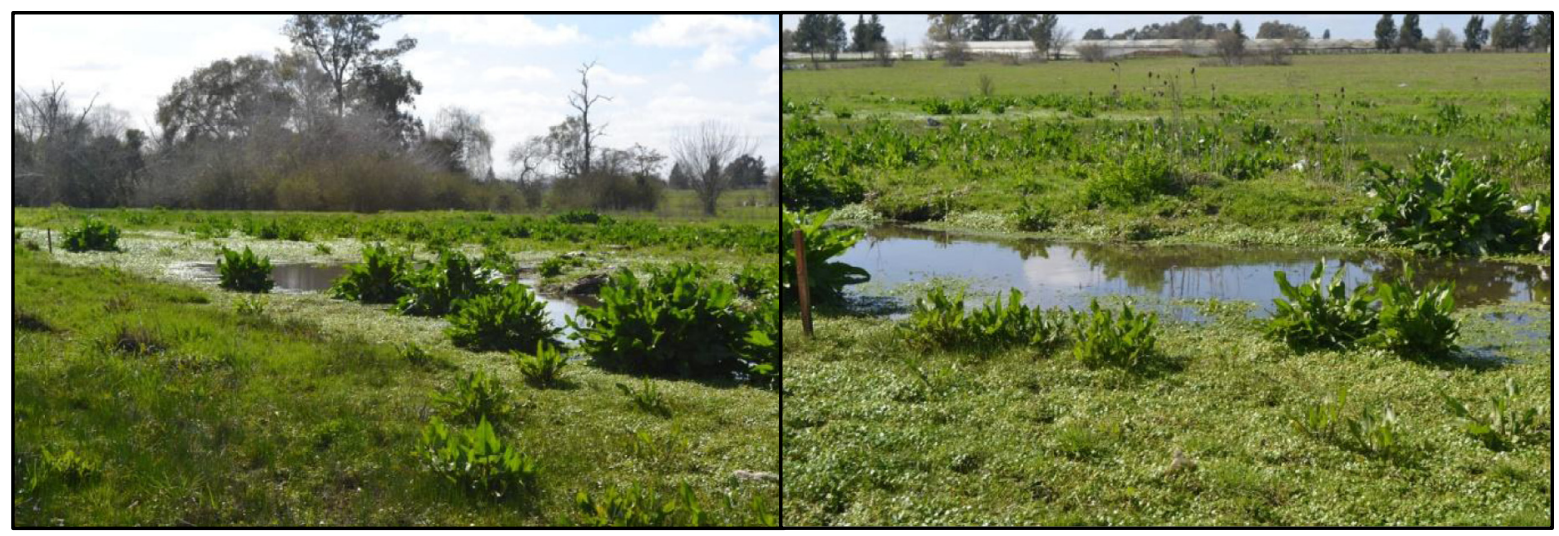

(b)

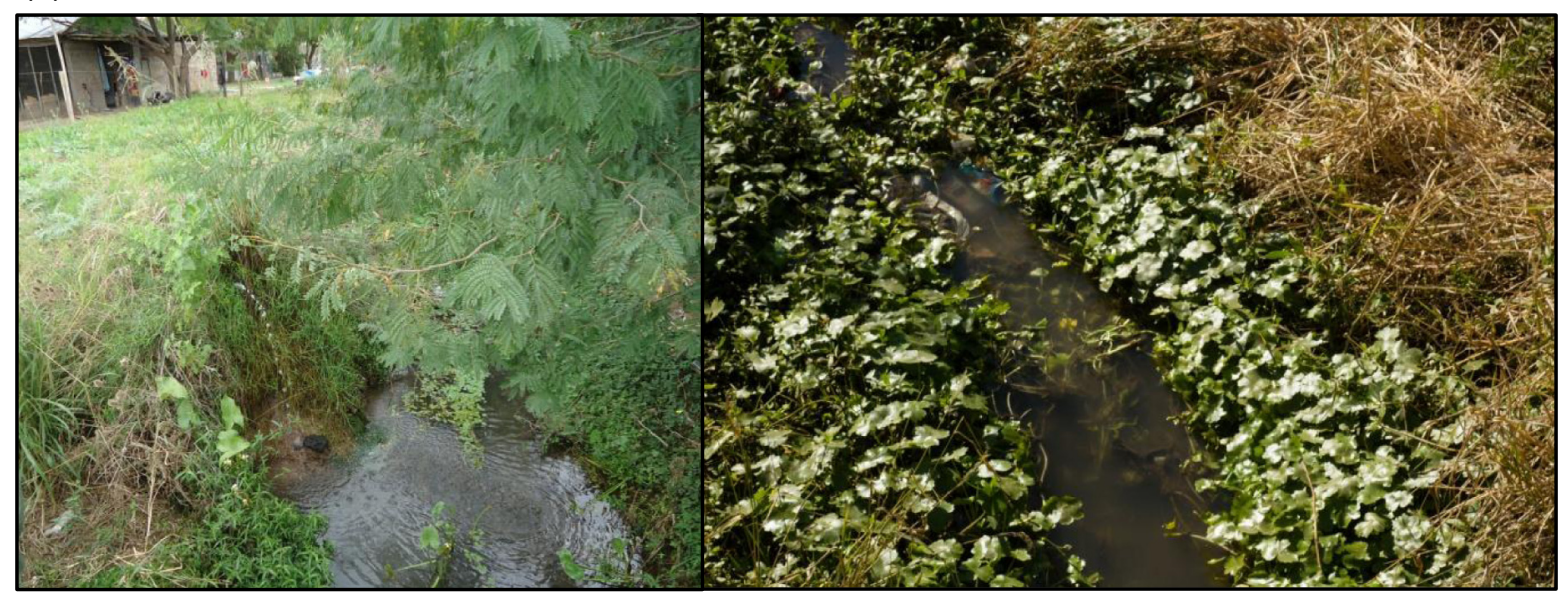

(c)

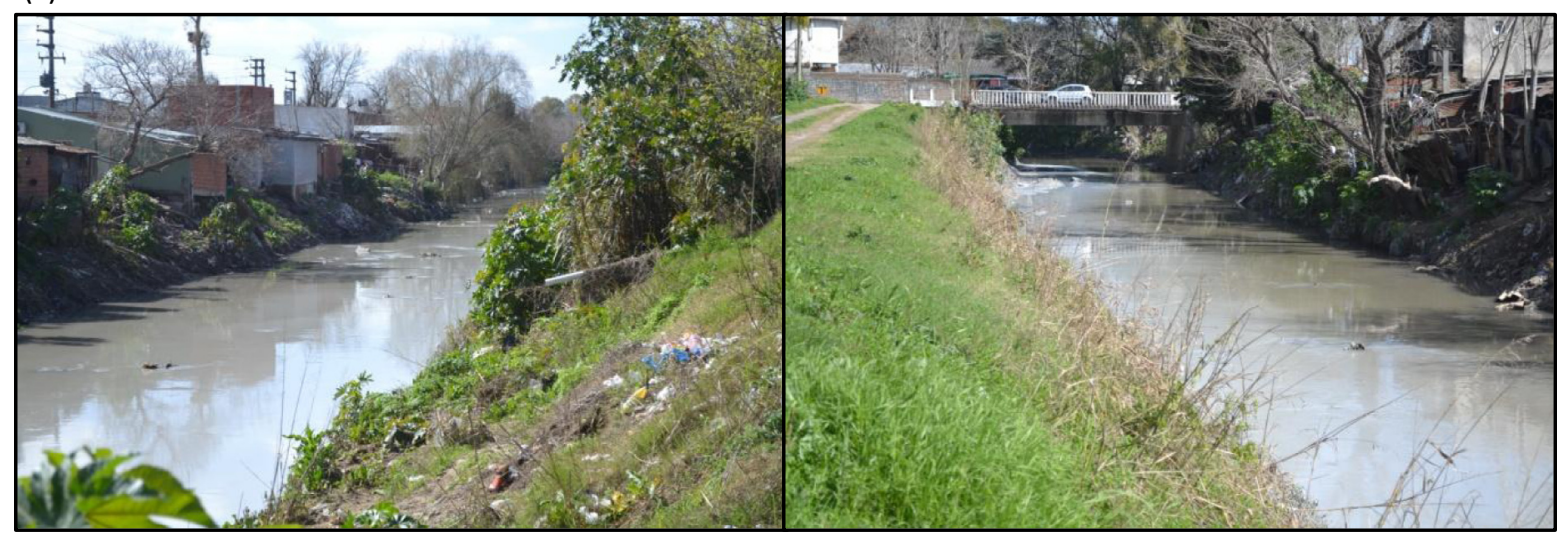

Fig. 2. Photographs of the sampling sites indicating the land use in Del Gato basin. (a): Site 1, in a rural area with intensive fruit and vegetable farming; (b): Site 2, in a periurban zone with additional commercial and industrial activities; (c): Site 3, in an urban area with a high population density and containing precarious dwellings, where sewers and industrial discharges are located in certain sectors.

analysis of correspondence (DCA) by segments was performed to determine if the taxa analyzed had responded linearly to gradients or had done so according to some environmental optimum. The maximum length of the gradient obtained in this analysis was 1.73 (standard-deviation units), which value indicated a strong linear response. A redundancy analysis (RDA) was thus performed in order to explore the relationship between the abundance of taxa and the environmental variables registered at the study sites (ter Braak and Verdonschot, 1995). The abundance values of the individuals were transformed to $\log (x+1)$ in order to reduce the weighting of the dominant groups, with all the taxa being included in the analysis (Tab. 1). Upon standardization of the physicochemical variables registered, the inflation values 
L.C. Armendáriz et al.: Knowl. Manag. Aquat. Ecosyst. 2017, 418, 32

Table 1. Taxa registered in the Del Gato stream basin during the study period along with the abbreviations used in Figure 5.

\begin{tabular}{|c|c|c|c|}
\hline Taxa registered & Abbreviations & Taxa registered & Abbreviations \\
\hline Cnidaria Hidrydae & Cni & Ephemeroptera Baetidae & $\mathrm{Bae}$ \\
\hline Platyhelminthes Dugesiidae & Dug & Caenidae & $\mathrm{Cae}$ \\
\hline Nematoda & Nem & Odonata Coenagrionidae & Coe \\
\hline Nematomorpha Gordioidea & & Aeshnidae & Aes \\
\hline Oligochaeta Naididae & Nai & Libellulidae & \\
\hline Opistocystidae & Opi & Diptera Chironomidae & Chir \\
\hline Enchytraeidae & Enc & Ceratopogonidae & Cer \\
\hline Megadrili & Meg & Ephydridae & Eph \\
\hline Hirudinea & Hir & Sciomyzidae & Scio \\
\hline Polychaeta Aeolosomatidae & Aeo & Psychodidae & Psy \\
\hline Bivalvia Sphaeriidae & Spha & Empididae & Emp \\
\hline Gastropoda Ampullariidae & Ampu & Stratiomyidae & Str \\
\hline Planorbidae & Pla & Culicidae & \\
\hline Physidae & Phy & Muscidae & Mus \\
\hline Hydrobiidae & Hyd & Tabanidae & \\
\hline Ancylidae & Anc & Dolichopodydae & \\
\hline Acochlidiacea & & Tipulidae & \\
\hline Copepoda Cyclopidae & Cyc & Phoridae & \\
\hline Diaptomidae & & Coleoptera Hydrophilidae & Hydro \\
\hline Cladocera & Cla & Scirtidae & Scir \\
\hline Ostracoda & Ost & Noteridae & \\
\hline Amphipoda Hyalellidae & Нya & Dytiscidae & Dyt \\
\hline Collembola Isotomidae & Iso & Curculionidae & Cur \\
\hline Poduridae & Pod & Elmidae & \\
\hline Sminthuridae & Smi & Hemiptera Belostomatidae & Bel \\
\hline \multirow{2}{*}{ Entomobryidae } & & Corixidae & \\
\hline & & Acari Hydrachnidia & Aca \\
\hline
\end{tabular}

obtained proved to be less than 20 . Those variables failing to pass the test of significance (i.e., temperature, $\mathrm{pH}, \mathrm{N}-\mathrm{NO}_{2}{ }^{-}$, $\mathrm{N}-\mathrm{NH}_{4}{ }^{+}$, chemical-oxygen demand, organic matter) were excluded from analysis. The statistical significance of the model with respect to the first axis as well as the canonical axes was evaluated by the Monte-Carlo test (499 permutations under the reduced model, $p<0.05$ ). The first two axes of ordination were selected for graphical representation.

\section{Results}

The following submerged and emergent macrophytes were collected at each of the sampling sites: in the bog adjacent to Site 1, Egeria densa (Planch.) Comm. ex Lam, Ludwigia peploides (Kunth) Raven, and Senecio bonariensis Hook. and Arn; at Site 2, Hydrocotyle bonariensis, Alternanthera philoxeroides (Martius) Grisebach, Typha latifolia (L.) Dulac, and the filamentous alga Mougeotia C. Agardh (Chlorophyta). At Site 3, however, no vegetation was present either in the watercourse or along the banks.

The physicochemical parameters and nutrients measured at the sites analyzed varied between the following values: temperature, $10.2{ }^{\circ} \mathrm{C}$ (Site 1 ) and $23.5^{\circ} \mathrm{C}$ (Site 3); turbidity, 13 NTU (Site 2) and 800 NTU (Site 3); pH, 6.6 (Site 1) and 8.3 (Site 3); conductivity, $246 \mu \mathrm{S} \mathrm{cm}^{-1}$ (Site 1) and $1210 \mu \mathrm{S} \mathrm{cm}^{-1}$ (Site 3); dissolved-oxygen concentration, $1.8 \mathrm{mg} \mathrm{L}^{-1}$ (Site 3) and $13.4 \mathrm{mg} \mathrm{L}^{-1}$ (Site 1); percent saturation of oxygen, 22 (Site 3) and 176 (Site 1); $\mathrm{P}-\mathrm{PO}_{4}{ }^{-3}, 0.158 \mathrm{mg} \mathrm{L}^{-1}$ (Site 2) and
$0.989 \mathrm{mg} \mathrm{L}^{-1}$ (Site 1); $\mathrm{N}-\mathrm{NO}_{3}{ }^{-}, 0.013 \mathrm{mg} \mathrm{L}^{-1}$ (Site 1) and $0.377 \mathrm{mg} \mathrm{L}^{-1}$ (Site 2); $\mathrm{N}-\mathrm{NO}_{2}{ }^{-}, 0.002 \mathrm{mg} \mathrm{L}^{-1}$ (Site 1) and $0.331 \mathrm{mg} \mathrm{L}^{-1}$ (Site 3); N-NH${ }^{+}, 0.001 \mathrm{mg} \mathrm{L}^{-1}$ (Site 1) and $1.251 \mathrm{mg} \mathrm{L}^{-1}$ (Site 3); biochemical-oxygen demand, $1.0 \mathrm{mg}$ $\mathrm{L}^{-1}$ (Site 1) and $35 \mathrm{mg} \mathrm{L}^{-1}$ (Site 3); and chemical-oxygen demand, $9.0 \mathrm{mg} \mathrm{L}^{-1}$ (Site 1) and $195 \mathrm{mg} \mathrm{L}^{-1}$ (Site 3). Table 2 gives the corresponding average values.

Some 53 taxa were identified over the entire study period (Tab. 1). From sites 1 through 3, the composition of the macroinvertebrate assemblage analyzed by application of the ecological indices exhibited a marked reduction in the average values for family richness (i.e., 33:25:12) and for the IBPamp (i.e., 8:7:3) from the upper- to the lower-basin sites (Fig. 3a). The family richness registered a maximum value $(S=38)$ at Site 1 in August of 2015, whereas the minimum $(S=10)$ occurred at Site 3 in October of 2014. Significant differences $(p<0.001)$ were found in this last index among the three sites, with each one differing significantly from the others. The Shannon diversity values varied between 1.48 (Site 3 in August 2015) and 1.99 (Site 2 in May 2015); but the differences among the three sites were not statistically significant $(p=0.226$; Fig. $3 b)$. Likewise, the values for diversity as estimated by the exponential of the Shannon index failed to achieve statistical significance (data not shown).

The IBPamp index (Fig. 3a) indicated levels of contamination that were from undetectable to moderate (i.e., 7-10) at Site 1, from moderate to light (i.e., 6-8) at Site 2, and from high to very high (i.e., 2-4) at Site 3. This analysis demonstrated 
L.C. Armendáriz et al.: Knowl. Manag. Aquat. Ecosyst. 2017, 418, 32

Table 2. Mean values of the limnologic parameters measured at the sampling sites in the Del Gato stream basin.

\begin{tabular}{|c|c|c|c|c|c|c|c|c|c|}
\hline & \multicolumn{3}{|c|}{ Site 1} & \multicolumn{3}{|c|}{ Site 2} & \multicolumn{3}{|c|}{ Site 3} \\
\hline & Oct-14 & May-15 & Aug-15 & Oct-14 & May-15 & Aug-15 & Oct-14 & May-15 & Aug-15 \\
\hline $\mathrm{T}\left({ }^{\circ} \mathrm{C}\right)$ & 18.0 & 10.8 & 10.9 & 21.7 & 13.1 & 14.2 & 23.2 & 17.0 & 16.7 \\
\hline Turbity (NTU) & 86.2 & 77.7 & 54.0 & 47.8 & 20.4 & 14.7 & 752.7 & $>800$ & $>800$ \\
\hline $\mathrm{pH}$ & 7.11 & 7.10 & 7.28 & 7.26 & 7.60 & 7.65 & 8.28 & 7.97 & 7.87 \\
\hline Conductivity $\left(\mu \mathrm{S} \mathrm{cm}^{-1}\right)$ & 311.7 & 565.7 & 523.3 & 692.3 & 766.7 & 727.0 & 1113.3 & 1203.3 & 1071.3 \\
\hline $\mathrm{DO}\left(\mathrm{mg} \mathrm{L}^{-1}\right)$ & 11.6 & 10.4 & 9.6 & 9.2 & 10.6 & 6.6 & 3.6 & 1.9 & 7.1 \\
\hline DO (\% sat.) & 149.0 & 119.7 & 88.9 & 111.1 & 104.7 & 66.0 & 37.7 & 60.7 & 75.3 \\
\hline $\mathrm{P}-\mathrm{PO}_{4}{ }^{3-}\left(\mathrm{mg} \mathrm{L}^{-1}\right)$ & 0.696 & 0.543 & 0.702 & 0.249 & 0.161 & 0.203 & 0.780 & 0.966 & 0.844 \\
\hline $\mathrm{N}-\mathrm{NO}_{3}{ }^{-}\left(\mathrm{mg} \mathrm{L}^{-1}\right)$ & 0.030 & 0.663 & 0.944 & 0.810 & 1.352 & 1.065 & 0.705 & 0.369 & 0.292 \\
\hline $\mathrm{N}-\mathrm{NO}_{2}{ }^{-}\left(\mathrm{mg} \mathrm{L}^{-1}\right)$ & 0.004 & 0.035 & 0.031 & 0.109 & 0.128 & 0.118 & 0.274 & 0.325 & 0.241 \\
\hline $\mathrm{N}-\mathrm{NH}_{4}{ }^{+}\left(\mathrm{mg} \mathrm{L}^{-1}\right)$ & 0.035 & 0.042 & 0.107 & 0.420 & 0.404 & 0.485 & 0.779 & 0.745 & 0.631 \\
\hline $\mathrm{BOD}\left(\mathrm{mg} \mathrm{L}^{-1}\right)$ & 5.7 & 2.0 & 7.0 & 2.3 & 11.7 & 10.0 & 31.0 & 23.3 & 32.0 \\
\hline $\operatorname{COD}\left(\mathrm{mg} \mathrm{L}^{-1}\right)$ & 23.3 & 9.7 & 14.0 & 40.7 & 23.3 & 13.0 & 97.3 & 36.3 & 195.0 \\
\hline
\end{tabular}

significant differences $(p=0.019)$ between sites 1 and 3 and between 2 and 3, but not between sites 1 and 2 .

The value for the density of macroinvertebrates (Fig. 3b) fluctuated between 2000 ind $^{-2}$ (Site 3 in October 2014) and 38600 ind $^{-2}$ (Site 2 in August 2015), though the variations registered between the sites and between the sampling occasions were not statistically significant $(p=0.096)$. Likewise the density of the macroinvertebrates in the benthos was not correlated with the content of organic matter in the sediments $(p=0.642)$.

Although - like the taxon richness and the biotic index the percent of the contamination-sensitive taxa (Fig. 3c) reflected a tendency to decline in the direction of the lower basin (i.e., 13:10:6), those differences were not significantly different either $(p=0.481)$. With respect to contaminationsensitive taxa at Site 3 in August 2015, a sole specimen of the Cladocera was recorded that could have been borne there from the upstream sites by the current.

In the PCA results (Fig. 4), the first two axes represented $75.6 \%$ of the variance accumulated from the dataset (Axis 1 eigenvalue, 0.496; Axis 2 eigenvalue, 0.260). The sampling sites were organized such that Site 1 (the adjacent marsh) was located in the upper left quadrant in association with the dissolved-oxygen concentration, Site 2 in the lower quadrants correlated with the $\mathrm{NO}_{3}{ }^{-}$values, and Site 3 in the upper right quadrant in strong association with the turbidity and the two oxygen demands.

Figure 5 presents the RDA results indicating the ordination of the taxa with respect to the environmental variables under investigation. For greater clarity, only those taxa with a $5 \%$ or greater frequency of appearance (cf. Tab. 1) are included. The two principal axes represent $56.9 \%$ of the variance accumulated from the dataset (Axis 1 eigenvalue, 0.118; Axis 2 eigenvalue, 0.075; statistical significance of the first canonic axis, $p=0.024$ and of all the axes, $p=0.004$ ). The variables most highly correlated with Axis 1 were $\mathrm{N}-\mathrm{NO}_{3}{ }^{-}(r=0.69)$ and $\mathrm{P}-\mathrm{PO}_{4}{ }^{-3} \quad(r=0.60)$, and those with Axis 2 were conductivity $(r=0.69)$ and dissolved-oxygen concentration $(r=0.79)$. With respect to the biota, in the upper right quadrant - it associated with high conductivity levels - were located the oligochaetes Megadrili and Enchytraeidae and the insects Psychodidae (with the last two families being registered at only sites 2 and 3) along with the Stratiomyidae (found in all three sites). All these taxa were present both in the benthos and in the vegetation. In addition, in the lower left quadrant, associated with the dissolved-oxygen concentration were located, among other groups, the coleopterans Hydrophilidae, the ephemopterans Baetidae, and the hemipterons Belostomatidae along with the Cnidaria and the polychaetes Aeolosomatidae (taxa registered only in the bog at Site 1). These groups were recorded only in association with the aquatic vegetation, with the sole exception of the aeolosomids, which taxon was found also in the sediment of the bog at Site 1.

\section{Discussion}

One of the principal reasons for the protection and proper management of the wetlands is the vast number of functions, services, and values characteristic of these regions. Their functions comprise the processes carried out within those aquatic systems and are independent of society perceptions, while their values depends on society attitudes, which change over time and among cultures (Brinson, 2004). The functions of the wetlands include the regulation of freshets; the retention of nutrients, sediments, and contaminants; the maintenance of the trophic networks; the consolidation of the banks; the control of erosion; the protection during storms; and the stabilization of the local weather conditions, particularly with respect to rainfall and the temperature.

The values of these wetlands - either direct or indirect include the maintenance of human well-being and the quality of the environment. In addition, these ecosystems generate services such as constituting sources of wildlife, fish, and silvae; terrains for the development of farming; and a wellspring of animal forage and water - with all of these services occurring as a result of the interactions among the constitutive biologic, chemical, and physical components of the wetlands. In this way, these environments present attributes that comprise the biologic diversity in addition to the ecosystem's cultural and patrimonial characteristics (Malvárez and Lingua, 2004).

Moreover, these natural wetland environments provide both basic materials and ecologic services for the subsistence and development of human societies: indeed, a healthy 
(a)

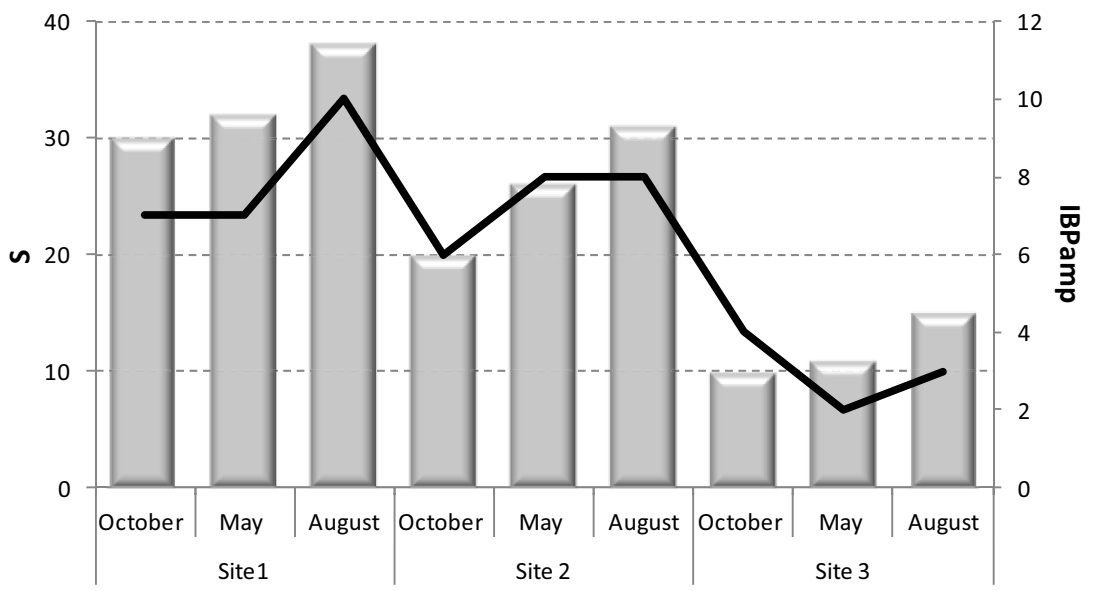

(b)

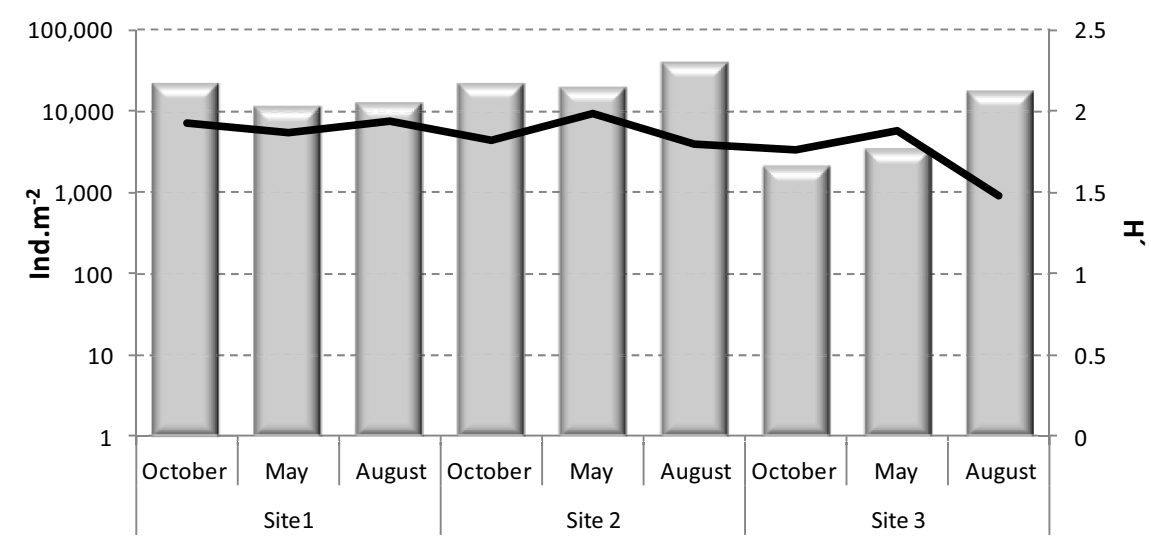

(c)

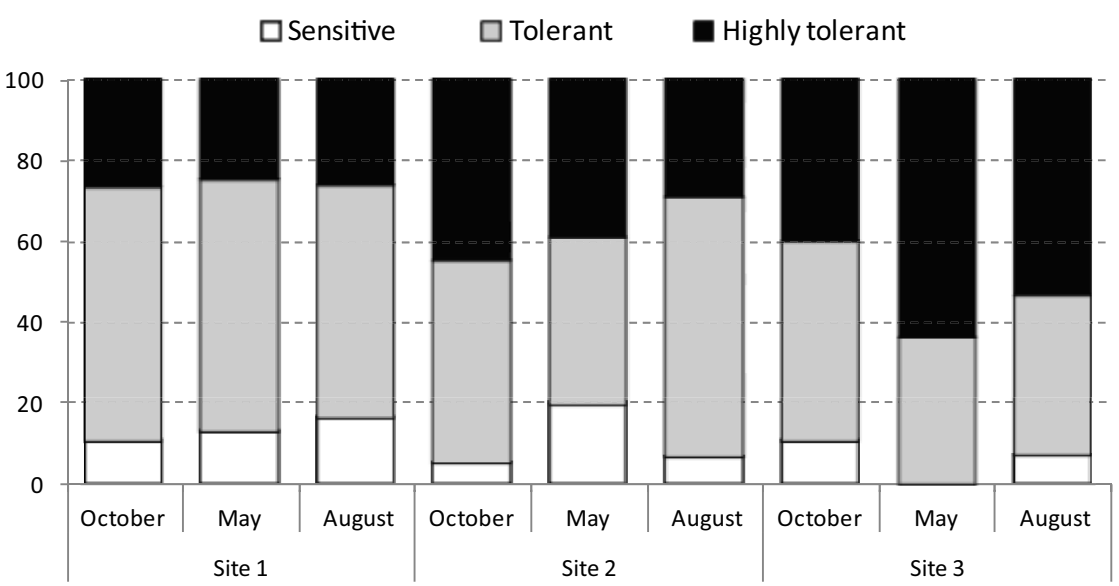

Fig. 3. Macroinvertebrates registered at the study sites in the Del Gato stream basin from October 2014 through August 2015. (a): Family richness (S, left ordinate and grey bars) and the biotic index for the pampean rivers (IBPamp, right ordinate and black line) are plotted for each of the months at the three study sites indicated on the abscissa. (b): Invertebrate density (ind $\mathrm{m}^{-2}$, left ordinate and grey bars) and Shannon diversity $\left(\mathrm{H}^{\prime}\right.$; right ordinate and black line) are plotted for each of the months at the three study sites indicated on the abscissa. (c): Percentage of sensitive (white bar color), tolerant (grey bar color), and highly tolerant (black bar color) taxa are plotted on the ordinate for each of the months at the three study sites indicated on the abscissa.

ecosystem guarantees the sustainability of human development. In recent decades, the notion of ecosystem services (Gómez et al., 2016; Wantzen et al., 2016) has become widely recognized as those natural ecologic functions that are useful for and a benefit to mankind - perhaps as a counterpart to the increasing anthropic impact on the environment that the 


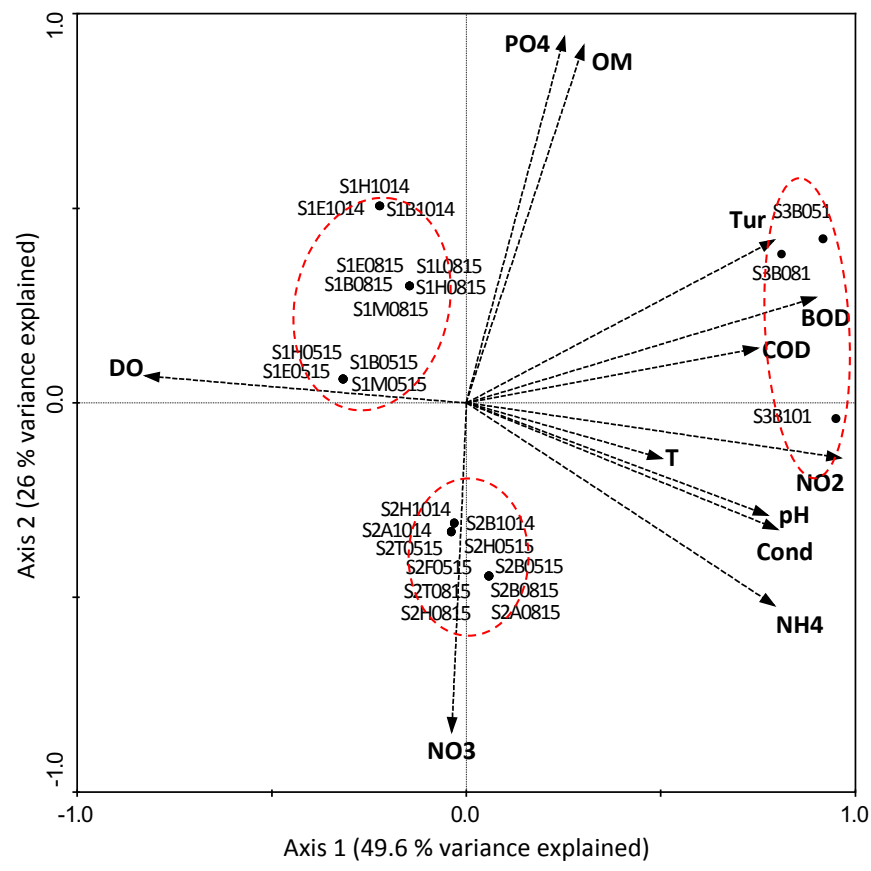

Fig. 4. Graphical representation of the two primary axes (Axis 2, ordinate; Axis 1, abscissa) of the principal-components analysis (PCA) demonstrating the ordination of the sampling sites with respect to the environmental variables. Key to abbreviations: S1, Site 1; S2, Site 2; S3, Site 3; B, benthos; E, Egeria densa; L, Ludwigia peploides; M, Senecio bonariensis; H, Hydrocotyle bonariensis; A, Alternanthera philoxeroides; T, Typha latifolia; and F, Mougeotia; 1014, October 2014; 0515, May 2015; 0815, August 2015. Physicochemical parameters: conductivity, Cond; turbidity, Turb; nitrates, $\mathrm{NO}_{3}{ }^{-}$; nitrites, $\mathrm{NO}_{2}{ }^{-}$; ammonium, $\mathrm{NH}_{4}{ }^{+}$; phosphates, $\mathrm{PO}_{4}{ }^{-3}$; dissolved-oxygen concentration, DO; chemical-oxygen demand, COD; biochemical-oxygen demand, BOD; and organic matter in the sediments, OM. The areas demarcated by the broken red lines indicate the same sampling site.

development of human society has produced. Because of their intensive use and ever increasing demand as a resource, the ecologic status of the rivers of the world is worsening at a much greater rate than the majority of the terrestrial ecosystems (Wantzen et al., 2016). The concept of a healthy river is becoming more and more vague; and in many instances, as a response to the problem of contamination, societies have opted for a river that is canalized or covered over with concrete. In contradistinction to such practices and this lamentable general situation, urban and periurban development must be accompanied by new technologies and creative management options that are expressly directed at maintaining and improving the proper functioning of the aquatic ecosystems and their biotic diversity in order to achieve a permanent status of sustainability for these priceless wetlands.

In view of these considerations, during the decade of the 1980s the concept of ecosystem health became fully formulated in relation to the necessity to achieve a sustainable development in combination with new ideas and methods for environmental management (Rapport, 1989). Accordingly, the evaluation of ecosystem health became always one of the key considerations in environmental management (Peng et al., 2015) along with the essential understanding that ecosystems

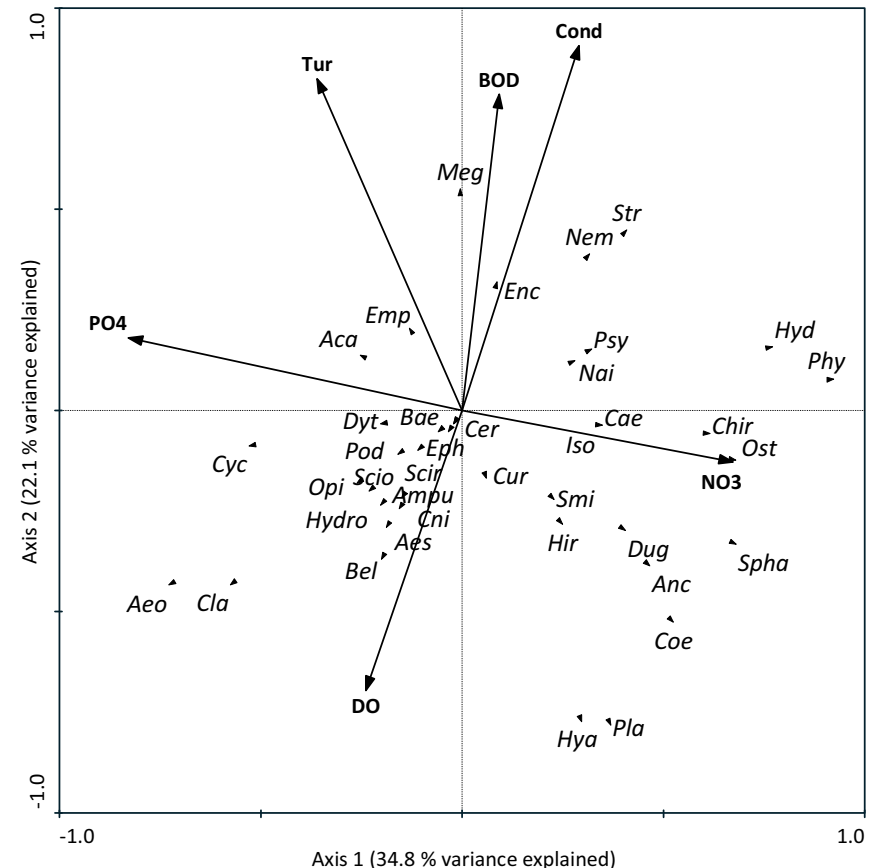

Fig. 5. Biplot of the analysis of redundancy (RDA) showing the ordination of the taxa with respect to the environmental variables measured at the study sites. In the figure, Axis 2 is the ordinate and Axis 1 the abscissa. For the abbreviations of the taxa, $c f$. Table 1. For the purpose of clarity, the figure includes only those taxa that were present at a frequency of $5 \%$ or greater. Key to abbreviations for the physicochemical parameters: conductivity, Cond.; turbidity, Tur.; nitrates, $\mathrm{NO}_{3}{ }^{-}$; phosphates, $\mathrm{PO}_{4}^{-3}$; dissolved-oxygen concentration, DO; biochemical-oxygen demand, BOD.

and human societies are intimately interrelated. Likewise, the notion of ecosystem health constitutes a framework for formulating questions related to the evaluation of environmental management and the strategies and policies to be used for attaining sustainability (Connell, 2010). Within this context, a growing consensus has arisen that the measurement of an ecosystem's health must include considerations of its organization (e.g., biodiversity and the structure of the trophic network), its vigor (as reflected in the rates of production and nutrient cycling), and its inherent resilience (i.e., the capacity to recover from perturbations) (Bunn et al., 2010).

Notwithstanding, the continually increasing urbanization worldwide continues to forge changes in the landscape that produce a major impact on natural ecosystems and impose pressing challenges for the sustainability of the rivers therein (Alberti et al., 2007). These alterations associated with progressive urbanization have been highly significant during the last half century and furthermore are expected to continue as such in the decades to come. Because of this circumstance, the ecologic condition of rivers throughout the world becomes all too often progressively degraded by human activities in the areas surrounding the basins, thus propelling the health of the aquatic systems into an ever decreasing spiral - a situation, therefore, demanding an urgent vigilance on the part of the controlling authorities in regulating those anthropic activities in order to attain a lasting sustainability. 
During the processes of urbanization, the ecologic conditions of natural systems are significantly influenced by four variables: the intensity of the use of the surrounding land, the land cover composition, the configuration of the landscape, and connectivity of the impervious area (Alberti et al., 2007). This impermeability of the soil effected by different types of constructions, the resulting acceleration of runoffs, the installation of obstacles to the flow of water, the contamination, and man-made modifications to streams and rivers in urban areas - all these influences perturb the hydrologic systems, modify the flow of energy and the cycling of nutrients, and alter the quality of the water and the ecologic status of the streams. These adverse conditions are at the same time recognized as the principal drivers that contribute to a magnification of the untoward consequences of storms within urban and periurban areas (Gómez et al., 2016). Urbanization also has a negative impact on the riverbanks since the resulting loss of habitats there reduces the overall capacity of the hydrographic basin to filter nutrients and sediments, thus diminishing the quality of the water and undermining the health of the aquatic ecosystems (Alberti et al., 2007; Bunn et al., 2010; Basílico et al., 2016).

Among the characteristics that distinguish the SouthAmerican continent, the wetlands are unique and the most extensive within the global biosphere in proportion to the continental masses (Neiff and Malvárez, 2004). The majority of those ecosystems are found in the drainage basins of the major rivers in the tropical, subtropical, and temperate climatic areas. Within those wetlands, the bogs adjacent to rivers and streams and the floodplains play a prominent role, acting as highly dynamic mosaics of ecosystems, where the stability and diversity are conditioned primarily by the hydrology and the flow of materials (Ezcurra de Drago et al., 2007).

Numerous papers have described studies demonstrating the vital role of runoff marshes in providing the habitat for a wide diversity of biota (Blendinger and Alvarez, 2002; Martínez et al., 2009). Nevertheless, only few investigations carried out in those natural bogs have utilized macroinvertebrates as bioindicators. One of the most fundamental ecosystem services provided by such marshes involves their ability to act as attenuators of flooding. Moreover, the South-American wetlands in general support the development of an abundant and diverse variety of aquatic floating, submerged, and emergent plants that provide a plethora of habitats for invertebrates, fish, and birds. In addition, those environments exhibit a marked seasonality during the spring and summer periods, at that time supporting the development of flourishing vegetation, as well as during the autumn and winter, when especially the emerging aquatic vegetation becomes reduced (Gómez et al., 2016).

The present investigation demonstrated that the composition of the macroinvertebrate assemblage, as analyzed through the application of ecological indices, exhibited a marked decrease in family richness and the IBPamp index in passing from the upper to the lower basin. The percentage of contamination-sensitive taxa also underwent the same gradient, therefore indicating deterioration in the ecologic quality in that part of the basin. Neither the index of diversity nor the density of invertebrates present, however, was found to correlate with the different uses of the land in the study area. Likewise, Cuffney et al. (2010) observed that the taxon richness revealed a closer association with urbanization than the values for invertebrate abundance, while the diversity indices were also poorly correlated. In many situations involving the need to evaluate the impact of human activities on biologic systems, the final result may be a decline in the abundance of only certain species in a community, though without causing the complete disappearance of any; thus producing a small, or even negligible, effect on the index of diversity (Jost and González-Oreja, 2012).

The deterioration in the quality of the water in the lower basin also became manifest in the chemical parameters analyzed. The PCA results demonstrated that Site 2 was distinguished by the levels of $\mathrm{N}-\mathrm{NO}_{3}{ }^{-}$, those being the highest registered during the entire study period, whereas Site 3 was strongly associated with the biochemical- and chemicaloxygen demands. By the year 2050, one-third of the world population is estimated to encounter problems related to an excess of nitrogen in water at the same time as one-fifth will be living in environments at high risk of water of poor quality because of excessive biochemical-oxygen demand - i.e., exceedingly high levels of biodegradable organic compounds (Connor, 2016). From the decade of the 1990s, the levels of contamination have increased in all the rivers of Latin America, principally because of the discharge of untreated wastewater into the watercourses; and in 2010 from 6 to $10 \%$ were calculated to have been affected by severe organic contamination with concentrations measured by biochemical-oxygen demand at greater than $8 \mathrm{mg} \mathrm{L}^{-1}$ (Hoa and Lamizana, 2016).

Although the unprecedented flooding occurring in La Plata on April 2 and 3, 2013 should be considered an anomaly, nevertheless in this region other occasions of major precipitation (for example, in 2002 and 2003) have been registered that likewise caused extensive flooding; and those incidents, furthermore, became progressively more catastrophic. The environmental deterioration that the region of La Plata has experienced as a result of the area's uncontrolled population growth, urbanization, and industrialization has contributed to an ever increasing risk of extreme flooding from the standpoint of hydrologic and healthcare parameters.

The conservation of biologic diversity and the management of ecosystems have traditionally been perceived as issues falling within the ambit subsuming the action and responsibility of national governments. Nevertheless, a local form of administration - especially because of its competence in matters of urban planification - can generally assume a decisive and relevant role more conveniently. The rational use of wetlands contributes to the consolidation of sustainable urban and periurban zones, from both the environmental and the social point of view. One of the principal causes of the degradation and loss of wetlands in urban and periurban areas is the lack of awareness regarding the economic and social value of those ecosystems as well as the services that they provide. Therefore, in keeping with Resolution XI 11 (Ramsar, 2012), management alternatives such as the formulation of more sensitive and comprehensive policies of urban planification would be proposed to include: (1) a landscaping and spatial zonification aimed at the protection of the wetlands and the ecosystem services they provide; (2) an enhancement of the awareness on the part of governments and citizens concerning the benefits offered by the wetlands and the need for their continued conservation; and (3) an education of the society in general as to the relevance of the wetlands as key elements to 
be taken into consideration in urban planning, in the management of watercourses and drainage systems, and in the treatment of water. That this vision must be shared in common and must involve the participation of committed individuals in a cooperative and integrated approach including the scientists, politicians, administrators, and members of the community is indeed essential.

The present work, along with previous investigations on the bog adjacent to the Del Gato stream (Gómez et al., 2016), evidences the fundamental role of such marshes in the maintenance of good environmental conditions. Flooding is a natural catastrophe that causes particular damage in Argentina: in the last 50 years, 75 major floodings have been registered that affected 13 million persons. This phenomenon represents a danger not only from the volume of water involved but also from the materials and contaminants that are dragged along resulting in a sanitation hazard. Within this context, an essential function of those adjacent marshes is the potential attenuation of the gross pluviometric excesses that could become increasingly catastrophic within this region according to the predictions made on the basis of the changing climate (Buytaert et al., 2016).

\subsection{Proposals for planning in the Del Gato stream basin}

The approach of ecologic restoration involves a study of the strategies and techniques for the recuperation of degraded ecosystems and the services that they provide. In those instances, where a return to the original state is impossible, the rehabilitation is an adequate alternative. The processes of restoration and rehabilitation are both dynamic and must be adapted to the local socioenvironmental conditions.

Thus, in the Del Gato basin, different actions would be necessary in accordance with the specific problems present. In the upper basin, for example, where the adjacent marsh is located, the implementation of certain restrictions in the use of the land could create a buffering zone where the watercourse would become wider without damaging anything. To that end, policies and laws should be implemented for the creation and protection of such an area of easement. That zone, as delimited by those norms, would remain free from activities that could result in an increase in greenhouses or housing projects that would contaminate the stream with nutrients and impermeabilize the soil.

In the intermediate sectors of the basin, the disposal of household refuse and garbage must be controlled and the appropriate conditions of the riverbanks maintained by avoiding further housing and the introduction of impermeable areas. The communication centers of the National University at La Plata are carrying out projects to educate and heighten the awareness of the population regarding environmental care and especially the economic and social value of the wetlands and the services their ecosystems offer.

The lower basin receives the greatest degree of anthropic impact and is therefore the target for the majority of the remedial actions to be pursued. In that sector of the basin, hydraulicengineering projects are under way to increase the surface of the riverbed, and the decision has been made to relocate the cellulose plant that releases a considerable volume of chemical contamination into the stream. Nevertheless, the following measures are urgently needed: the decontamination treatment of the domestic and industrial effluents, the management of rainwater, the elimination of obstacles to the flow of water (such as the perennial garbage in the stream), the relocation of the residents who occupy the areas adjacent to the most vulnerable stretches to less sensitive sites, and finally the rehabilitation of the banks through the reintroduction of native-plant species whether in the form of seeds, plantules, or planted rolls. The presence of macrophytes in the water promotes the extraction of nutrients, especially the nitrates and the dissolved solids; and the periphyton established on the roots and submerged parts of the plants contributes to the elimination of nutrients and contaminants in the sediments. These last steps will take advantage of the climate and latitude of the region, conditions favor the rapid growth of macrophytes. Moreover, the establishment of those plants at the site will eventually promote the colonization of invertebrates, which taxa will serve as the prey for birds and other vertebrate predators. In the end, the reconstitution of the ecosystems there will enable the exploitation of the ecologic services that the stream and its affluents offer.

Acknowledgements. The research was supported by Proyecto PIO 13420130100004CO: (CONICET-UNLP): "Evaluación y análisis de Riesgo Ambiental en el área Gran La Plata" and a grant from Agencia Nacional de Promoción Científica y Tecnológica, FONCYT PICT 810. The authors would like to thanks Jorge Donadelli from the Laboratory of Chemistry of the ILPLA, for the nutrient and oxygen-demand analysis of the water samples; Luciana de Tezanos for her collaboration with the map and Roberto Hensen for his assistance in fieldwork. This Scientific Contribution $\mathrm{N}^{\circ} 1001$ was from the Instituto de Limnología "Dr Raúl A. Ringuelet". The help of Dr. Donald F. Haggerty, a retired academic investigator and native English speaker, with the translation of the original Spanish manuscript is also appreciated.

\section{References}

Alberti M, Booth D, Hill K, et al. 2007. The impact of urban patterns on aquatic ecosystems: an empirical analysis in Puget lowland subbasins. Landsc Urban Plan 80: 345-361.

Basílico G, de Cabo L, Faggi A, Miguel S. 2016. Low-tech alternatives for the rehabilitation of aquatic and riparian environments. In: Ansari AA, Gill SS, Gill R, Lanza G, Newman L, eds. Phytoremediation: management of environmental contaminants. Switzerland: Springer, pp. 349-364.

Blendinger PG, Alvarez ME. 2002. Ensambles de aves de los bañados de Carilauquen (Laguna Llancanelo, Mendoza, Argentina): consideraciones para su conservación. El Hornero 17: 71-83.

Brinkhurst RO, Marchese MR. 1992. Guía para la identificación de oligoquetos acuáticos continentales de Sud y Centroamérica. Colección Climax No. 6. Santo Tomé, Argentina: Asociación de Ciencias Naturales del Litoral.

Brinson MM. 2004. Conceptos y desafíos de la clasificación de humedales. In: Malvárez AI, ed. Documentos del curso-taller: bases ecológicas para la clasificación e inventario de humedales en Argentina. Argentina: Pcia de Buenos Aires, pp. 25-33.

Bunn SE, Abal EG, Smith MJ, et al. 2010. Integration of science and monitoring of river ecosystem health to guide investments in catchment protection and rehabilitation. Freshw Biol 55(Suppl. 1): 223-240.

Buytaert W, Mishra A, Demuth S, et al. 2016. El cambio climático y los eventos extremos. In: Agua y Empleo. Informe de las Naciones 
Unidas sobre el Desarrollo de los Recursos Hídricos en el Mundo. París: WWAP - Programa Mundial de Evaluación de los Recursos Hídricos de las Naciones Unidas, UNESCO.

Cabrera AL, Fabris HA. 1948. Plantas acuáticas de la provincia de Buenos Aires. Argentina: Publicación Técnica, Continuación de la Serie D.A.G.I., Min. Hacienda, Econ y Previsión, Dir. Agropecuaria.

Collier KJ. 2008. Temporal patterns in the stability, persistence and condition of stream macroinvertebrate communities: relationships with catchment land-use and regional climate. Freshw Biol 53: 603-616.

Connell DJ. 2010. Sustainable livelihoods and ecosystem health: exploring methodological relations as a source of synergy. EcoHealth 7: 351-360.

Connor R. 2016. Situación de los recursos de agua dulce. In: Agua y empleo. Informe de las Naciones Unidas sobre el Desarrollo de los Recursos Hídricos en el Mundo. París: WWAP - Programa Mundial de Evaluación de los Recursos Hídricos de las Naciones Unidas, UNESCO.

Cuffney TF, Brightbill RA, May JT, Waite IR. 2010. Responses of benthic macroinvertebrates to environmental changes associated with urbanization in nine metropolitan areas. Ecol Appl 20: 1384-1401.

Díaz B. 1982. La Plata. Una Obra de Arte, 1882-1982. Gobierno de la Provincia Buenos Aires, Universidad Nacional de La Plata, Municipalidad de la Plata.

Domínguez E, Fernández HR. 2009. Macroinvertebrados bentónicos sudamericanos. Sistemática y biología. Tucumán, Argentina: Fundación Miguel Lillo.

Elosegi A, Sabater S. 2009. Conceptos y técnicas en ecología fluvial. Spain: Rubes Editorial.

Ezcurra de Drago I, Marchese MR, Montalto L. 2007. Benthic invertebrates. In: Iriondo MH, Paggi JC, Parma MJ, eds. The Middle Paraná River: Limnology of a Subtropical Wetland. Berlin, Heidelberg: Springer-Verlag.

Feio MJ, Dolédec S. 2012. Integration of invertebrate traits into predictive models for indirect assessment of stream functional integrity: a case study in Portugal. Ecol Indic 15: 236-247.

Gómez N. 1998. Use of epipelic diatoms for evaluation of water quality in the Matanza-Riachuelo (Argentina) a pampean plain river. Water Res 32: 2029-2034.

Gómez N, Rodrigues Capítulo A, Colautti D, et al. 2016. La puesta en valor de los servicios ecosistémicos que ofrecen los arroyos de llanura como una medida de mitigación de las inundaciones: el caso del $\mathrm{A}^{\circ}$ Del Gato en el Partido de La Plata. In: Volpedo AV, de Cabo L, Arreghini S, Fernández Cirelli A, eds. Ecología y manejo de ecosistemas acuáticos pampeanos. Buenos Aires, Argentina: VIII EMEAP.

Hoa E, Lamizana B. 2016. La salud de los ecosistemas. In: Agua y Empleo. Informe de las Naciones Unidas sobre el Desarrollo de los Recursos Hídricos en el Mundo. París: WWAP - Programa Mundial de Evaluación de los Recursos Hídricos de las Naciones Unidas, UNESCO.

Jost L, González-Oreja JA. 2012. Midiendo la diversidad biológica: más allá del índice de Shannon. Acta Zool lillo 56(1-2): 3-14.

Karr JR. 1991. Biological integrity: a long-neglected aspect of water resource management. Ecol Appl 1: 66-84.

Malvárez AI, Lingua G. 2004. Lineamientos para una clasificación e inventario de humedales. Un aporte conceptual. In: Malvárez AI, ed. Documentos del curso-taller: bases ecológicas para la clasificación e inventario de humedales en Argentina. Argentina: Pcia de Buenos Aires, pp. 109-114.
Martínez F, Lucero F, Calí R, Valdés D, Ferrer D, Chebez JC. 2009. Registros novedosos de aves para las provincias de Mendoza y San Juan. Nótulas Faunísticas 35(segunda serie): 1-9.

Merritt RW, Cummins KW, Berg MB. 2008. An introduction to the aquatic insects of North America, 4th ed. Iowa, USA: KendallHunt Publishing Company.

Morosi JA. 1999. Ciudad de La Plata. Tres décadas de reflexiones acerca de un singular espacio urbano. Argentina: La Plata, Comisión de Investigaciones Científicas, Provincia de Buenos Aires.

Neiff JJ. 2001. Humedales de la Argentina: sinopsis, problemas y perspectivas futuras. In: Cirelli AF, ed. El Agua en Iberoamerica, Funciones de los humedales, calidad de vida y agua segura. Argentina: CYTED, pp. 83-112.

Neiff JJ, Malvárez AI. 2004. Grandes humedales fluviales. In: Malvárez AI, ed. Documentos del curso-taller: bases ecológicas para la clasificación e inventario de humedales en Argentina. Buenos Aires, Argentina, pp. 77-88.

Lopretto E, Tell G. 1995a. Ecosistemas de aguas continentales. Metodología para su estudio, Tomo II. La Plata, Argentina: Ediciones Sur.

Lopretto E, Tell G. 1995b. Ecosistemas de aguas continentales. Metodología para su estudio, Tomo III. La Plata, Argentina: Ediciones Sur.

Peng J, Liu Y, Wu J, Lv H, Hu X. 2015. Linking ecosystem services and landscape patterns to assess urban ecosystem health: a case study in Shenzhen City, China. Landsc Urban Plan 143: 56-68.

Ramsar. 2012. Resolución XI.11: Principios para la planificación y el manejo de los humedales urbanos y periurbanos. In: 11th Meeting of the Conference of the Parties, RAMSAR, Bucharest. http://www. ramsar.org/sites/default/files/documents/pdf/guide/guide-urbansp.pdf.

Rapport DJ. 1989. What constitutes ecosystem health? Perspect Biol Med 33: 120-132.

Rodrigues Capítulo A. 1999. Los macroinvertebrados como indicadores de calidad de ambientes lóticos en el área pampeana. Rev Soc Entomol Argent 58(1-2): 208-217.

Rodrigues Capítulo A, Gómez N, Armendariz L, et al. 2016. Programa de Monitoreo Integrado de Calidad de Agua Superficial y Sedimentos de la Cuenca Matanza-Riachuelo y Sistematización de la Información Generada. Cuenca Matanza-Riachuelo. Campañas Octubre 2015-Marzo 2016. Aspectos biológicos y del hábitat. Convenio Específico entre la Secretaría de Medio Ambiente y Desarrollo Sustentable de la Nación (SAYDIS)-ACUMAR-y la Facultad de Ciencias Naturales y Museo, UNLP. http://www. acumar.gov.ar.

Rodrigues Capítulo A, Tangorra M, Ocon C. 2001. Use of Benthic macroinvertebrate to assess the biological status of Pampean streams in Argentina. Aquat Ecol 35(2): 109-119.

Romanazzi P. 2014. Aproximación a la estimación estadística de la Precipitación Máxima Probable (PMP) para La Plata, Provincia de Buenos Aires, Argentina. Argentina: Actas del II Congreso Internacional de Hidrología de Llanuras Santa Fe.

Shannon C. 1948. A mathematical theory of communication. Bell Syst Tech $J$ 27: 379-423.

ter Braak C, Verdonschot P. 1995. Canonical correspondence analysis and related multivariate methods in aquatic ecology. Aquat Sci Res Across Bound 57: 255-289.

Wantzen KM, Ballouche A, Longuet I, et al. 2016. River Culture: an eco-social approach to mitigate the biological and cultural diversity crisis in riverscapes. Ecohydrol Hydrobiol 16: 7-18.

Cite this article as: Armendáriz LC, Cortese B, Rodriguez M, Rodrigues Capítulo A. 2017. Ecosystem services of runoff marshes in urban lowland basins: proposals for their management and conservation. Knowl. Manag. Aquat. Ecosyst., 418, 32. 